Article

\title{
Exploring Value Creation in Sustainable Entrepreneurship: Insights from the Institutional Logics Perspective and the Business Model Lens
}

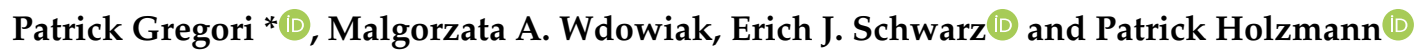 \\ Department of Innovation Management and Entrepreneurship, University of Klagenfurt, 9020 Klagenfurt, \\ Austria; malgorzata.wdowiak@aau.at (M.A.W.); erich.schwarz@aau.at (E.J.S.); patrick.holzmann@aau.at (P.H.) \\ * Correspondence: patrick.gregori@aau.at
}

Received: 28 March 2019; Accepted: 26 April 2019; Published: 29 April 2019

\begin{abstract}
Sustainable entrepreneurs intend to create environmental and social value while they build their financially viable business. With this in mind, they are embedded in multiple institutionalized value systems (i.e., institutional logics) that provide them with different, often contradictory values, beliefs, and guiding principles. Adhering to these value systems and integrating multiple forms of value into a coherent business model is a key task for sustainable entrepreneurs, yet current efforts lack insight into how this can be achieved. To address this, the article utilizes the institutional logic perspective in conjunction with the componential approach to business models. By analyzing a longitudinal in-depth case study, this article develops a novel theoretical model linking shifts in the entrepreneur's perception of institutional logic to business model alterations, and emphasizes the underlying mechanisms and behavior of the sustainable entrepreneur. Sustainable entrepreneurs integrate and blend institutional logic through multiple business model transitions, which are characterized by a personal reorientation of the entrepreneur and new practices to implement change. Furthermore, our findings show that the entrepreneur's habitus, the pre-change business model, and the change-specific dominant logic are integral and previously overlooked concepts that contextualize their business model transition. The findings and discussion advance the theoretical and practical understanding of the processes through which sustainable entrepreneurs integrate multiple forms of value into their business models. With that, the article contributes to research on sustainable entrepreneurship, institutional logic and business models.
\end{abstract}

Keywords: sustainable entrepreneurship; institutional logics; business models; change process; habitus

\section{Introduction}

"I recognized that one should not only pay attention to those things that are important in the 'normal world, i.e., the business world', but that there are also other values to which you can attach importance and still be successful". (Simon)

Humanity faces complex and severe environmental and social challenges, which in past decades have steered the public and political discourse towards the notion of sustainable development [1]. In this respect, the debate on these fundamental challenges has advanced into the realm of entrepreneurship studies [2-4]. Entrepreneurship has been thrust into the spotlight as a possible solution to environmental and social problems where entrepreneurs create and exchange non-economic and economic value based on financial feasibility [3,5]. In their quest to develop "commercially viable ventures that advance causes of environmental protection and social justice" [6], they follow distinct values, beliefs, and assumptions anchored in the institutionalized value systems of environmentalism and social welfare, 
leading to a different prioritization of venture goals and value creation $[7,8]$. This stands in contrast to the conventional ways of conducting business in more 'traditional' forms of entrepreneurship, which is dominated by the logic of the market $[7,9,10]$. Furthermore, due to the variety of objectives, that sustainable entrepreneurs intend to balance, they are confronted with a more complex entrepreneurial process than their 'traditional' counterparts [11,12]. Having to prioritize and balance multiple value systems to create environmental, social, and economic value can then lead to tensions and conflicts that need to be ameliorated within a coherent business model $[13,14]$.

However, knowledge about how entrepreneurs approach this key task, as well as how and if they create value beyond economic profit in conjecture with their other goals, remains an area that needs to be explored in depth $[7,15,16]$. In relation to this, research on how entrepreneurs develop their ventures, and respectively their business models, that is coherent in itself and with the entrepreneur's aspirations, is still in its infancy and further inquiries are needed $[13,15,17]$. Specifically, we lack longitudinal studies that investigate how sustainable entrepreneurs experience potential tensions, follow different values, beliefs, and guiding principles, and develop and change their business accordingly $[15,18]$. This research aims to open this 'black box'.

To address this, we derive a novel approach of analysis combining the framework of the institutional logic perspective $[7,19,20]$ and the business model lens $[14,15,21,22]$. Recent research posits that these theoretical perspectives provide a considerable opportunity to investigate sustainability-related entrepreneurship $[9,14,23,24]$. The institutional logic (In this article we use 'institutional logics' and 'logics' interchangeably) perspective allows an exploration of the cultural embeddedness of sustainable entrepreneurs, and locates the entrepreneur in the wider social, cultural, and institutional context [25]. It aims to understand how individuals deal with multiple and often contradictory values, beliefs, and norms $[19,26,27]$. In this vein, sustainable entrepreneurship research has started to acknowledge the embeddedness of the entrepreneur within multiple institutional logics (e.g., environmental protection, social welfare, and commercial market logics) at the same time, potentially leading to tensions between different forms of value creation $[6,7,9,14,20]$. Further, we utilize the business model lens $[14,15]$. Business models illustrate how the entrepreneur designs the creation, capture, and exchange of value while exploiting business opportunities $[28,29]$. With that, business models provide an analytical device to inspect how sustainable entrepreneurs strive for multiple forms of value and how these values are embedded in activities, structures, and relationships of the entrepreneur's emerging organization [14].

Building on the theoretical framework of institutional logic and business models, we aim to answer the following interrelated research questions:

RQ1: How do sustainable entrepreneurs experience multiple institutional logics (i.e., cultural embeddedness) while they develop their business?

RQ2: How do sustainable entrepreneurs integrate and blend values, beliefs, and norms of multiple institutional logics within their business model?

To answer these research questions, we introduce the concepts of the institutional logic perspective, sustainable entrepreneurship, and business modelling. We conduct a longitudinal in-depth case study and follow a grounded theory approach [30-34]. Data collection included semi-structured interviews, as well as other sources of information for data triangulation. Based on the initial results, we develop an original theoretical model that provides new insights concerning the perception of multiple logics, a personal reorientation of the entrepreneur, change implementation practices, and business model outcomes. The theoretical model emphasizes previously underexplored mechanisms of change in sustainable entrepreneurship. Findings show that sustainable entrepreneurs carry out several transition phases to integrate multiple logics within their business model. We stress the importance of the entrepreneur's habitus, their pre-change business model, and the change-specific dominant logic as concepts to contextualize the transition processes. Thus, our study contributes to the research on sustainable entrepreneurship, institutional logic, and business models. Finally, we derive theoretical and managerial implications, discuss the limitations of our study, and present potential avenues for future research. 


\section{Theoretical Foundations}

\subsection{The Institutional Logics Perspective}

The institutional logics perspective has its roots in sociological institutionalism as well as organization studies, and refers to a societal level of institutionalized cultural values, beliefs, and regulations [19,35]. Its beginnings are credited to Friedland and Alford's [27] seminal work, where the authors coined the term 'institutional logic' and developed a theoretical perspective due to the author's discontent with the lack of appreciation of cultural factors within institutional theories at that time. In their theoretical point of view, they sought to emphasize cultural influences on human behavior and how people organize their lives. The original work on institutional logic posits that societies are formed by core institutions (e.g., the market, family, religion, etc.), which all have their central logic entailing "a set of material practices and symbolic constructions-which constitutes its organizing principles" [27].

Building on recent theoretical developments, institutional logics are shared sets of values, beliefs, assumptions, and organizing principles, which individuals are culturally embedded in $[27,36]$. They constitute intersubjective meaning systems inhabited and enacted by actors focusing their attention, and with that, for example, frame goals or influence the valuation of what is desirable $[19,37,38]$.

A core premise of this perspective is that individuals are embedded in multiple institutional logics each with their own values, beliefs, norms and guiding principles and this can potentially lead to contradictions and tensions for organizations and individuals $[37,39]$. Thus, the main objective of this perspective is to help to understand how individuals deal with multiple and often contradictory cultural values and beliefs [26]. In recent years, the institutional logics perspective has experienced considerable scholarly attention $[19,37]$ and has been used in a wide range of different fields such as management [40], organization studies [30], or entrepreneurship [7,18].

\subsection{Sustainable Entrepreneurship}

A growing amount of scholarly work has identified and investigated sustainable entrepreneurs, who take an active role in contributing to environmental, social and economic sustainability $[5,41]$. In this vein, the field of entrepreneurship has begun to discuss the notion that entrepreneurial action is not solely a cause of social inequality and environmental degradation, but can be part of the solution to these challenges of humanity $[3,42]$. More and more scholars have contributed to the development of sustainable entrepreneurship, resulting in a vivid field of scientific inquiry in recent years $[43,44]$. Sustainable entrepreneurs exploit failures in markets, which deviate from sustainability [42] and with that, act in a market-oriented manner but in concert with the sustainable development goals [45].

Importantly, current literature argues that sustainable entrepreneurs strive for the creation of value beyond financial gains. They are framed as change agents tackling critical environmental and social issues by seizing sustainable opportunities and creating non-economic and economic value for today's and future generations alike [5,41,42]. We consequently refer to sustainable entrepreneurs when they intentionally combine ecological and social value creation based on a business case.

Sustainable entrepreneurs have different preferences than more 'traditional' types of entrepreneur. In this sense, their objectives go beyond self-interest and profit-orientation towards the creation of multiple forms of value $[3,46]$. As a result, scholars argue that sustainable entrepreneurs are predestined to be confronted with, and affected by different institutional logics (logics of the commercial market, environmental protection, and social welfare), which influence their goals and behavior $[6,9,20,47]$.

\subsection{Business Models}

The concept of business models often refers to how business is done. It is a portrayal of the core architecture of the enterprise and a dominant thinking pattern [29,48-51]. Based on the development of business model literature with its origins in e-business, the underlying value orientation, especially in theory, is incontrovertibly a commercial one, driven by a substantial customer focus with the 
aim to realize value in the form of profits and competitive advantages $[29,49,52,53]$. Yet, a growing body of literature in organizational, business model and entrepreneurship research is indicating a departure from the purely commercial context and a shift towards heterogeneous or hybridized ways of organizing with multiple goals such as sustainable venturing [54-57]. This increasing interest in non-commercial value creation and alternative forms of organization has opened ways for the reconceptualization of business models. Lately, scholars have reframed business models under the lens of the institutional logics perspective, acknowledging that business models are shaped by a multitude of institutional logics combining numerous values, beliefs, and assumptions for value creation [14,21,22].

Conceptualizations of business models may vary, but currently applied terminology seems to converge towards a componential approach, meaning that a business model is arranged by the interplay of different components with distinct functions [58,59]. A value proposition, value creation, value delivery, and value capture lie at the center of most conceptualizations [60,61]. Thus, in this article we refer to business models as the interplay of value proposition (what value is offered and to whom), value creation (how value is created), value exchange (how value is exchanged) and value capture (how value is captured) in a coherent whole [14].

\section{Research Framework-A Link between Institutional Logics, Business Models and the Sustainable Entrepreneur}

The theoretical framework acting as a launching point for our study is the synthesis of the concepts mentioned above. We build on the literature on the institutional logics perspective as well as sustainable entrepreneurship and draw a connection to business models, which has been recently proposed by scholars [14,21,22].

The core of this approach is that sustainable entrepreneurs are culturally embedded in different value systems (i.e., institutional logics) including the commercial market, environmental protection, and social welfare. It is theorized that this embeddedness then influences how individuals develop and design organizations [19]. For sustainable entrepreneurs, research has shown how multiple logics influence their venture goal creation, or their approaches to gain legitimacy $[7,20]$. Furthermore, Ocasio and Radoynovska [21], propose that the commitment of the entrepreneur "to particular combinations of logics can shape value creation and distribution among multiple stakeholders, ultimately affecting definitions and measures of organizational performance". This means that the entrepreneur makes the decision on how to integrate different available logics into the business model depending on the cultural embeddedness of the individual. The business model design-defined as the sum of the decisions that weave together activities performed by the venture and its stakeholders-constitutes a key set of practices for the entrepreneur $[62,63]$. This is even more the case when different logics are at play and the creation, exchange, and capture of multiple values are pursued $[64,65]$. Thus, the business model specifies how the actions of the entrepreneur under multiple institutional logics influences the development of the entrepreneurial venture.

While designing the business, the entrepreneur may be constrained by the salient logics as they, for example, can impute contradicting guiding principles, goals, or values. Yet, logics do not only constrain the decision-making of the embedded individual through taken-for-granted principles, but also enable it as they provide schemata for action and offer opportunities for creative action [19,30]. This link between multiple logics, the embedded entrepreneur and their actions influencing the development of the business model, as shown in Figure 1, provides the guiding framework for our inquiry. 


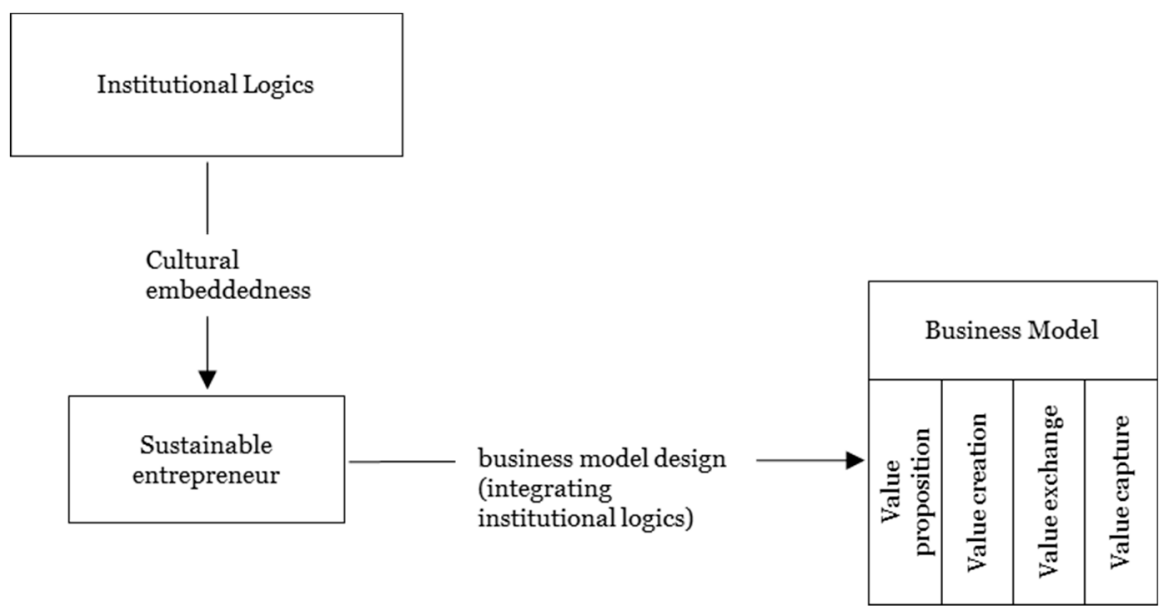

Figure 1. Initial research framework (based on [19]).

\section{Methodology}

\subsection{Research Design}

In general, qualitative research approaches yield great promise for investigating institutional logics [31]. Moreover, the relation between logics and the design of business models by sustainable entrepreneurs is still in its infancy, and researchers call for in-depth case studies to fully explore the phenomenon [15]. In this vein, we employ a longitudinal single case study design allowing for a detailed investigation into the matter at hand and embracing the contextual conditions [66]. Single case studies have been successfully used for studying organizational change and institutional logics $[18,30,67]$. The study utilizes an interpretative approach, which seeks to understand the meanings of phenomena and human experience in specific contexts $[68,69]$.

\subsection{Case Selection and Data Collection}

The unit of analysis is the development of the sustainable venture and the entrepreneur. The name of the entrepreneur in our case study is Simon and he is 28 years old. He grew up and was educated in Austria, but also worked as a volunteer in different countries all over Europe. In 2016 Simon founded his first venture that, at the time of case selection, had the objective to produce and sell upcycled and sustainable products with production sites in Uganda. This aimed at the empowerment of workers in Uganda, providing them with well-paid and safe jobs as well as educational opportunities as part of the social value creation. Yet, he also intended to create a positive environmental impact by using biodegradable materials procured in Uganda and upcycled plastic for production. As our research is interested in how entrepreneurs deal with multiple logics and how this affects their business model, the case selection was purposive. The entrepreneur fits the definition of sustainable entrepreneurship presented earlier [6] and hence provides a relevant case of the phenomenon for our study [68].

We chose the case due to its revelatory potential in developing new insights into the understudied topic [70]. First, the first-time entrepreneur is in the very early phase of venture development, providing the opportunity to follow the changes of business models and the establishment of the new venture. We were able to attain data from the pre-startup phase and to trace potential adjustments and changes in the venture development process. Related to this, the entrepreneur is a solo-entrepreneur and that allows us to connect his behavior directly to the business model without the additional complexities of entrepreneurial team members' influences. Second, the underlying case offers a business model where the environmental, social, and economic impact is deeply intertwined with the business model components. In addition, it experienced profound changes throughout the process. Thus, it offers a complex business model to study, which allows for a better portrayal of how different institutional logics influence the venture. Third, in the short time of venture establishment, the entrepreneur was 
able to gain a foothold in the field, including first sold products as well as positive feedback and support from business incubators, media, idea competitions and so on. This allows for access to rich data.

Data collection follows recommendations from case study research [66,70] and includes semi-structured and open interviews with the founder as well as persons close to the business (incubator coaches and technical freelancer). Additionally, archival data such as business plans, newspaper articles, website information, and other online media (e.g., videos), etc. are part of the data stock. An overview of the data sources is provided in Table 1. Formal data collection began in October 2017. Archival data (concepts, videos, presentations, etc.) and informal talks date back to early 2015 when the idea to start an entrepreneurial venture was initially sparked. The names of the participants have been anonymized.

Table 1. Data sources.

\begin{tabular}{|c|c|c|c|}
\hline Data Type & Source & $\#$ & Additional Information \\
\hline \multirow{5}{*}{ Interviews } & Entrepreneur (Simon) & 6 & Semi-structured interviews \\
\hline & $\begin{array}{l}\text { Business advisor } \\
\text { (Martha) }\end{array}$ & 2 & Semi-structured interviews \\
\hline & $\begin{array}{l}\text { Technical advisor } \\
\text { (Fabian) }\end{array}$ & 1 & Open interview \\
\hline & $\begin{array}{l}\text { Entrepreneurs of the } \\
\text { sports sector }\end{array}$ & 2 & $\begin{array}{l}\text { Open interviews, other sports startups close } \\
\text { to the entrepreneur }\end{array}$ \\
\hline & Sum Interviews & 11 & \\
\hline \multirow{5}{*}{ Additional Sources } & $\begin{array}{l}\text { Informal Talks with the } \\
\text { Entrepreneur } \\
\text { Documents }\end{array}$ & 24 & $\begin{array}{l}\text { Includes talks in informal settings between } \\
\text { the researchers and the entrepreneur } \\
\text { Includes weekly reports from the } \\
\text { accelerator program, business plans, and } \\
\text { business reports }\end{array}$ \\
\hline & Presentations & 3 & Presentations for grants and incubators \\
\hline & Videos & 5 & $\begin{array}{l}\text { Includes a short biography of the } \\
\text { entrepreneur from national TV, marketing } \\
\text { spots, and pitches of his ideas }\end{array}$ \\
\hline & $\begin{array}{l}\text { Newspaper and Blog } \\
\text { Articles }\end{array}$ & 5 & $\begin{array}{l}\text { Includes newspaper articles in national } \\
\text { newspapers as well as blog entries about } \\
\text { the entrepreneur and his activities }\end{array}$ \\
\hline & $\begin{array}{l}\text { Sum Additional } \\
\text { Sources }\end{array}$ & 59 & \\
\hline
\end{tabular}

\subsection{Data Analysis}

To analyze the data, we follow a grounded theory approach [32,33], which has been successfully utilized in studying the interpretation and enactment of institutional logic $[30,64,71]$. This allows for a deeper understanding and the uncovering of patterns based on the underlying meanings, as well as the incorporation of rich context and the capturing of the participant's values and beliefs [31,32]. Although there is an overarching framework positing the relationship between business modeling and logics, the link is still in development, which does not permit the derivation of pre-determined categories. 


\subsubsection{Case Narrative and Temporal Bracketing}

We started our analysis of the data in building a case narrative and rearranging acquired data corresponding to the timeline of the nascent venture development process of the entrepreneur. This allowed for an illustration of the key events and activities, such as changes in logic salience and business model changes. According to this timeline, we identified the starting point of the entrepreneurial process, namely a vacation of the entrepreneur in Uganda. There, he built social networks with locals, which created the basis for the subsequent venture development. The observation period ends in January 2019.

When sketching out the timeline (see Figure 2), we noticed critical events that changed the course of the entrepreneurial process profoundly, making some institutional logics more salient than others. Consequently, this changed the dominant goals and behavior of the entrepreneur. To engage these changes, we decided to utilize the notion of temporal bracketing [34] and divided the process into three phases - the establishment of his initial business model and two transition phases. Finding clear boundaries of such change processes can be difficult and one has to identify critical events that point towards these different phases [34]. The entrepreneur emphasized critical events in his practices as he, for example, changed the name of his project before or during the change processes.

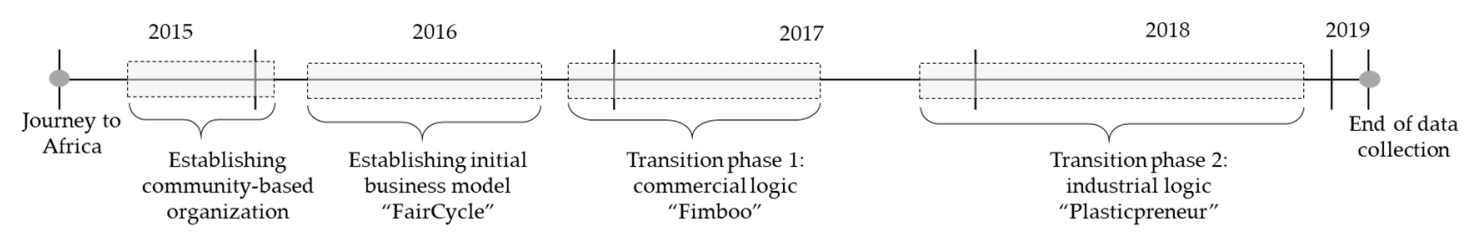

Figure 2. Timeline.

\subsubsection{Coding}

Data analysis follows the steps of inductive approaches of theory building as proposed by scholars of grounded theory $[32,33]$. First, we constructed a case chronology with a timeline to identify key events and activities as well as to get a grip on the data [72]. Second, data were open coded looking for potential interesting motifs, which are the foundation to establish first-order codes close to the text for further engagement. Third, the first-order codes were then grouped into second-order themes presenting more abstract and theory-driven lenses. This required an iterative analysis going back and forth between the related literature of first-order codes as well as raw data. The data structure is presented in Figure 3. Finally, the methods suggest the transposition of these second-order themes into aggregate dimensions from which we build a process model. 


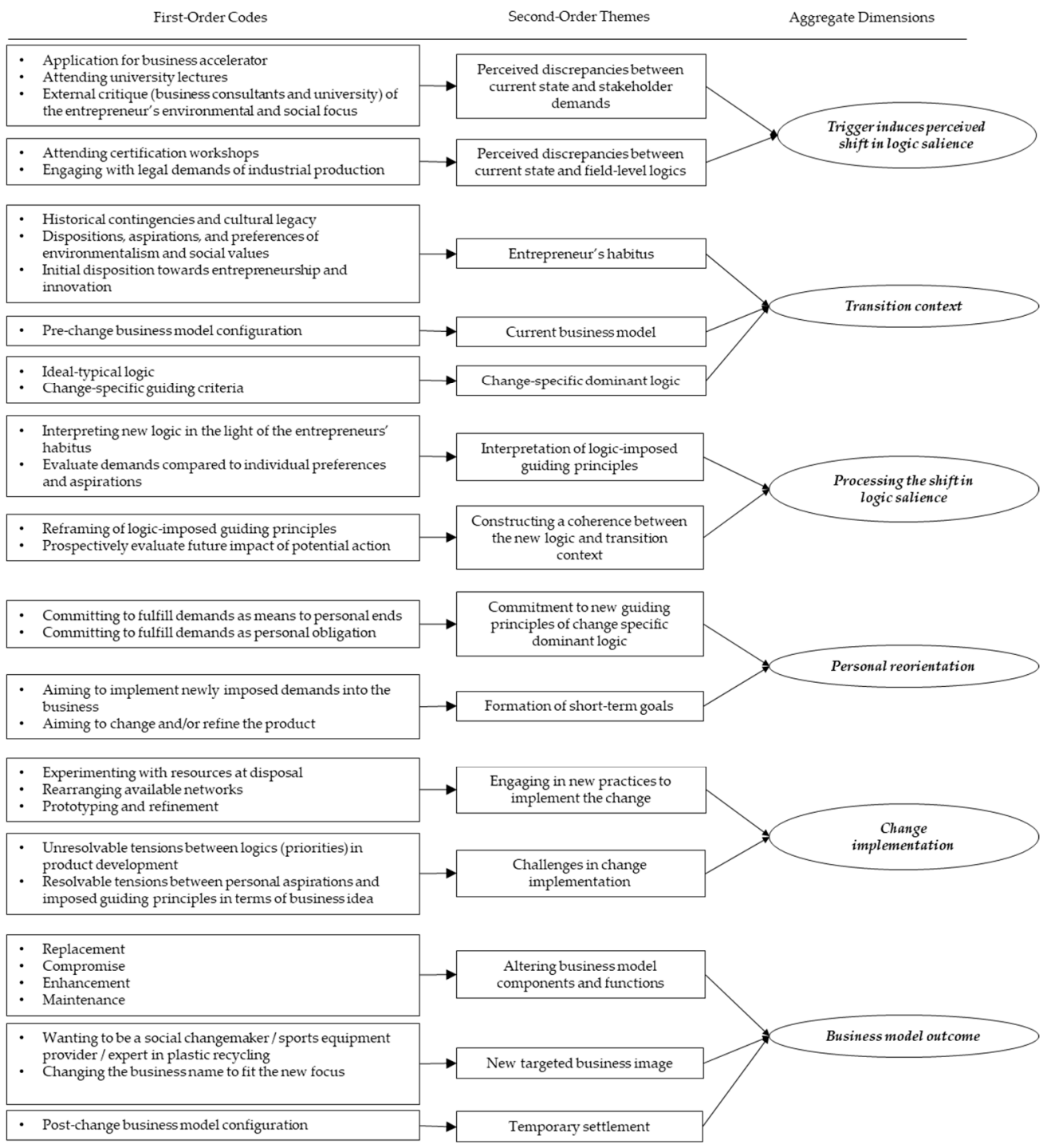

Figure 3. Data structure.

\section{Findings}

This section presents the findings of the case study focusing on our initial research questions: (1) how sustainable entrepreneurs experience multiple institutional logics while they develop their business and (2) how they integrate the associated values into a coherent business model.

After the initial establishment of the business model, the observed entrepreneur experienced two shifts in the salience of logics where newly emerging logics needed to be blended into the business model. We recognized that these shifts caused a series of changes in terms of his commitment, short-term goals, practices and subsequently his business model. Transition phase 1 is characterized by a sequence-specific dominance of the commercial market logic, highlighting the importance of commercial guiding principles, which the entrepreneur had to deal with. In transition phase 2, on the other hand, a logic of industrial production emerged as a new dominant logic along the transition phase. Both phases led to radical changes in the business.

Overall, data analysis revealed four logics—religious social welfare, environmental protection, commercial market, and industrial production-that influenced the entrepreneur and the entrepreneurial process to different degrees at different points in time. According to the concepts of current literature, we present these logics as ideal-types in Table 2. The social aspirations of the entrepreneur stemmed from his religious background, where social welfare is anchored in the holy texts 
and principles of the church. This led us to term this logic 'religious social welfare'. Environmental logics were reflected in his dispositions towards nature and his wider ecosystem.

Table 2. Ideal-typical institutional logics identified in the case.

\begin{tabular}{ccccc}
\hline Substance & Religious Social Welfare & Environmental Protection & Commercial Market & Industrial Production \\
\hline $\begin{array}{c}\text { Mission/Basis of } \\
\text { strategy }\end{array}$ & $\begin{array}{c}\text { Increase well-being of the } \\
\text { poor and needy }\end{array}$ & $\begin{array}{c}\text { Conservation of nature } \\
\text { and life }\end{array}$ & Financial capital & Technical sophistication and increase profit \\
\hline Guiding principles & $\begin{array}{c}\text { Empowerment, equality, } \\
\text { freedom, dignity }\end{array}$ & $\begin{array}{c}\text { Environmental-friendliness, } \\
\text { pristineness }\end{array}$ & $\begin{array}{c}\text { Profitability, customer focus, } \\
\text { Creation of quality products }\end{array}$ & Efficiency, quality, safety \\
\hline $\begin{array}{c}\text { Sources of } \\
\text { legitimacy }\end{array}$ & $\begin{array}{c}\text { Holy texts, gospel } \\
\text { principles of church }\end{array}$ & Integrity of the ecosystem & $\begin{array}{c}\text { Share price, market acceptance } \\
\text { (satisfying customer needs } \\
\text { and wants) }\end{array}$ & Industry standards \\
\hline Basis of norms & $\begin{array}{c}\text { Membership in a } \\
\text { community of faith }\end{array}$ & $\begin{array}{c}\text { Being part of the wider } \\
\text { ecological system }\end{array}$ & Self-interest & $\begin{array}{c}\text { International standard } \\
\text { organizations }\end{array}$ \\
\hline References & {$[19,23,73]$} & {$[40,74]$} & {$[9,19]$} & {$[30,75]$} \\
\hline
\end{tabular}

The process model of change we derived from our data is depicted in Figure 4. Findings show that triggers induce a shift in the logic salience and with that a change in the importance of guiding principles. The entrepreneur consciously perceives and processes the shift, including the interpretation and construction of internal coherence with the current situation and the new demands. Subsequently, a reorientation in terms of the current commitment as well as goals leads to new practices to implement the change including potential challenges. Here, the transition context-the entrepreneurs' habitus, the current business model, and change-specific dominant logic-are influencing factors of the entrepreneur's actions. This transition sequence leads to an evolution of the business model, altering components and functions. This acts as a temporary settlement for the newly-merged logics, or in other words, a state of relative stability where multiple logics are accommodated within the business [76].

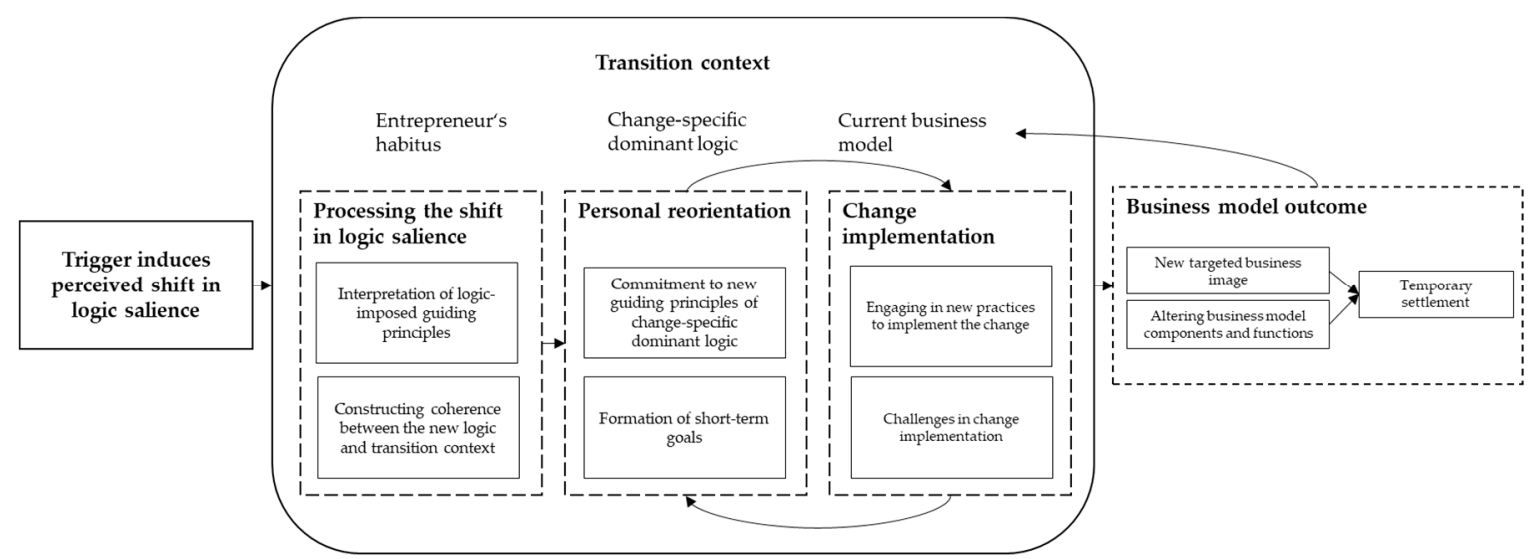

Figure 4. Business model transitions of sustainable entrepreneurs and the underlying mechanisms induced through a shift in logic salience.

In the following, we provide contextual information about the entrepreneur and his path of transformation into a nascent sustainable entrepreneur and show how the concepts of the process models emerged.

\subsection{Entrepreneur's Habitus and the Initial Business Model}

To understand the business model transitions and change processes that occurred in our research case, we found that the concept of habitus [77-79] provides a helpful lens to breach the chasm between institutional logics and their instantiation within sustainable business models $[13,14]$. Previous research shows the importance of past experiences in the process of habitus formation [77,80,81]. To clarify the picture of the entrepreneur's habitus, we elaborate on the early childhood and socialization (i.e., 
historical contingencies and cultural legacy [82]) of the entrepreneur and how his experience led to the initial business model.

The dominant logic characterizing the entrepreneur's habitus and with that his actions in everyday life is undoubtedly a social and environmental one. Helping people in need has been his social mission since his early childhood, which can also be attributed to his religious background. Simon became part of the Church of Jesus Christ of the Latter-day Saints when he was eight and the principles of the community have been an integral part of his life ever since. Simon talked about his social streak that has been a part of him since he was a little boy, which is tightly connected to his religious affiliation. For his faith, solidarity and being there for each other is an essential component, playing a big role in his personal development. Related to this, his religious affiliation also incorporates prudent, realistic, and balanced approaches to the environment, which are consistent with the needs of the earth, as well as current and future generations (e.g., careful handling of resources and reducing waste).

As reported by Simon, his parents, other family members, and friends were important influencing factors of his environmental and social dispositions. Guiding principles of the church, especially the obligation to help the poor and needy [73], are inhabited by him, woven into his habitus, and enacted throughout the course of his life. For example, he helped flood victims in Austria together with his parents, providing them with food and tools to overcome the tragic events. Further, in a decisive moment in his life, he gathered material donations for children who experienced the horrors of the Kosovo War:

"For me, it's my family upbringing. In my family, it was obvious that if problems appear in our neighborhood that we were the first ones to help. My parents were very helpful and, of course, we noticed that when we were children. But what I believe had a great impact on me was the time of the Kosovo war in the 1990s. A cheesy moment so to speak, and I can still remember it very well. As a part of the church community, my parents collected toys for children in the war. People brought us stuff and we packed and sent it to them when I was about six or seven years old. I didn't really understand what they were doing at the time, but they explained to me that there are children who aren't doing so well right now and that we are packing toys for them. At this time, I just received a new toy, a dinosaur from a gas station shop, from my dad. There, I struggled with myself, if I should put my new super-duper dinosaur in a donation-box or not? That's pretty much the only thing I can remember from that time. Somehow I decided to put my toy in the box-that really shaped $\mathrm{me}^{\prime \prime}$. (Simon)

It also led him to choose his education according to his wish to engage in development aid as an occupation. Starting with a technical school, followed by business management training in the area of humanitarian logistics at university.

Furthermore, data revealed that he has also been involved in environmental sustainability since his childhood, and through his occupation in the sports industry. Although not as dominant as his social aspirations, he and his wife also stated their profound affinity for nature and their aim to protect it:

"The environment is important for us for many reasons; on the one hand, we spend a lot of time in nature, but on the other hand we also know that we are dependent on nature-on the environment". (Simon's spouse)

He mentioned a vacation in Africa that was critical for his entrepreneurial efforts. In June 2015, Simon and his wife embarked on a trip to Uganda. A trip with the objective to expand their horizons and to get to know the culture and people of a foreign country. At that time, both were young students and short on money, so they organized the trip themselves. They used their religious affiliation to get in contact with locals and arranged places to spend their nights. This was the first step to gaining access and building a fundamental level of trust. Simon reported that the shared system of values and 
practices provided by their religious affiliation offered them the opportunity, not only to plan their trip, but also to gain deeper inside-views of the everyday life of the citizens.

"For example, if I go to church on Sunday, as it is usual, it is the same. No matter if I go to church in Klagenfurt [Austria] or in Uganda, these things are the same-people act the same, think the same, they have the same ideas and so on. As a result, you have a big network in the first few days". (Simon)

On-site, they worked with the locals and supported them in everyday tasks such as building their dwellings or growing crops in the fields. This is when the couple recognized that one can create an immensely positive impact for the local families with relatively simple means. He reported that, for example, harvesting fields, building houses, or repairing tools was possible without being experts. With common sense, they could provide substantial help and make practical progress.

This observation struck a chord. Motivated by their experience from the five-week trip to Uganda, Simon decided to set up a community-based organization with the aim to grant micro-credits based on donations, and with that the foundation for his subsequent entrepreneurial endeavors.

After establishing the community-based organization and a satisfying start, the entrepreneur pondered about how to expand this project and create more impact. During his trip to Africa, he noticed that the lack of mobility was making the Ugandans' everyday tasks such as going to work, school or the market, or reaching the next water well, rather difficult. Through online research, Simon stumbled across bicycles made of bamboo, which promised to be a sturdy and locally available material. Building such bikes would be an environmentally-friendly way to improve mobility and create further social impact-the idea of "FairCycle" was born.

During his studies in Austria, he worked on this idea and started to tinker with the materials and build first prototypes of bike frames made from bamboo. For the connection parts of the frame, he used recycled plastic. Together with friends, Simon built and tested the first prototypes. This is when he saw an advertisement for an innovation impact award - an idea competition, which at first did not go well with his environmental and social values:

"I then thought to myself, okay, that looks exciting but also, that it actually doesn't suit me at all—entrepreneurship and innovation-I couldn't do anything with these terms". (Simon)

However, he started to think about the option to make a living out of his self-defined sustainable mission of helping other people and protecting the environment. In the following weeks, Simon attended the idea competition with the first prototypes, won the award and gained access to a funded mentoring program.

“Through this incubator [... ] I got in contact with entrepreneurship and innovation [ ... ] For me, that was an immersion into a new world and a door opener for what I was always looking for in development aid but could not exactly find before". (Simon)

Motivated by this experience, Simon put his idea into practice. He started to use his networks from the community-based organization in Uganda and conducted workshops with Ugandans on how to build a sustainable bicycle. Subsequently, these workshops turned into a production site for the bicycles. Thus, he transformed his already established networks into potential employees, creating well-paid and safe jobs as an additional dimension to his social value creation. To create a financial basis, he aimed to sell the bikes in Europe. Thus, his first business model took shape.

The focus of his value proposition entailed the notion of providing Ugandan citizens with free mobility. Another social value proposed was the employment and education in the form of well-paid jobs and workshops for communities in Uganda, which he would achieve with his production site. The bike itself offered an environmental-friendly alternative for customers in Europe with similar functions to common bicycles. 
For the value capture of his business, Simon envisioned an environmental value capture in the form of $\mathrm{CO}_{2}$ and waste reduction by the utilization of bio-degradable material and recycled plastic. The social value capture included the improvement of the standard of living in Uganda. Through the bicycles, Ugandans were able to have easier and faster access to educational and medical facilities. Financial revenue streams were acquired through selling the product in Europe plus cross-financing with a donation system.

Bikes were planned to be sold through his own online-shop and distributed to Europe per ship, while the communication mostly conveyed the social production and environmental value of the product itself. These forms of distribution and communication constituted the core of his value exchange.

The production site in Uganda has been the core of the value creation of this business model version. There, his employees produced bicycles with local materials and recycled plastic.

\subsection{Transition Phase 1: Commercial Logic}

\subsubsection{Trigger Induces Perceived Shift in Logic Salience}

After setting up the foundations of his business, Simon produced the first prototypes in Uganda and took part in further training workshops as well as other competitions and awards. However, the entrepreneur sought to gain further financial support for subsequent prototyping. Simon approached an incubator, but with little success. The incubator coach, Martha, turned down his application and clarified the eligibility requirements of growth and market potential, i.e., scalability, profitability, and a customer focus-core principles of the commercial logic $[9,19]$ :

"It would have failed because of the scalability as well as its purpose and location. Simon has created something with the bicycle that is interesting for the market in Uganda, because the people there need the possibility to build a simple and cheap bicycle with existing raw materials or waste. This was not relevant for export. [ ... ] It became clear relatively quickly that we will not win a war with this. We need something relevant for the domestic market—for the Austrian and German market". (Martha)

A similar experience unfolded during a seminar at the university. The entrepreneur presented his "FairCycle" business model when the lecturers mentioned a possible product change to a simpler product, which he could produce and develop on his own and that was easier to transport from Uganda to Europe. He already had another product in mind. Namely, skiing and hiking poles made from the same materials of recycled plastic and bamboo.

The principles and values of the commercial logic became more salient in this phase and the entrepreneur was often confronted with decisions to withdraw from his environmental and social aspirations for the sake of the commercial point of view as stated by the incubator coach:

"At some point, he had to make an entrepreneurial decision, which took him quite some time. Does he offer an eco-product that's only suitable for customers, who are interested in a product, where everything is social and ecological, or does he offer a fun lifestyle product? [... ] That decision tormented him for a long time". (Martha)

Through these outside demands, the entrepreneur experienced a critique of his initial business model concerning the dominance of the ecological and social value and a lack of commercial value creation. Paired with the critique towards his product in terms of transportability and market focus, the entrepreneur had to engage with the commercial market logic.

\subsubsection{Processing the Shift in Logic Salience}

The outside demands, including the potential shift in products, and with that the change in value he would create, constituted a main problem for the entrepreneur. Changing his product meant 
changing the sustainability-related impact he would generate with the bicycle. He acknowledged that the bicycle was not interesting enough for investors, who could financially support his business. However, the value capture of mobility in Uganda was Simon's chosen way to achieve his personal mission and embodied values and beliefs and to support communities in need. Thus, a conflict between the commercial logic and the dispositions towards social welfare emerged.

In making sense of the multiple logics and to achieve coherence of the new guiding principles and his current situation, he started to reframe the demands influenced by his habitus. While prospectively evaluating the potential impact, the entrepreneur recognized that adhering to the logic would lead to a scalable product. In his case, scalability would also mean a higher environmental and social impact, because it opens the way to creating more jobs and higher rates of recycling. Further, through adhering to the demands, he could gain access to financial and knowledge support through the accelerator, which in turn would have positive effects on following his personal mission with his entrepreneurial project but also with potential other projects such as his community-based organization.

Reframing the new guiding principles of scalability, profitability, and customer-focus and distilling subjective advantages helped him to find coherence between the logic and his own preferences and goals as well as to find ways to follow the prescribed logics.

\subsubsection{Personal Reorientation and Change Implementation}

The change in salience towards the commercial logic and its associated guiding principles established the foundation for the reorientation of the entrepreneur in this specific phase. He committed to the new dominant commercial logic and its principles. Interestingly, at this point in time, he followed the new guidelines but reported in an interview that he did that by following his own interpretations. For example, for Simon, profitability is constituted by the foundation for subsistence and is reached if he can support his family. The potential of scalability, on the other hand, does not mean that one wants to and must scale with his products for better or worse. The commitment and the subsequent changes, the creation of a marketable product, fulfilling of the stakeholders' demands, and gaining access to financial capital, were meant to be means to achieve his ends-his environmental and social aspirations.

"Without all the funding there would be no other projects. If I produce plastic pegs in Uganda, I don't get a cent from anybody, but if I develop the same machines to produce an innovative product for our market it's something different". (Simon)

The entrepreneur formed new short-term goals, namely achieving a scalable product and business while preserving the positive ecological and social impact.

To reach his aims, Simon engaged in a wide range of new practices and the main changes entailed the product focus shift from the bicycle to the skiing poles (see Figure 5), emphasized by a change in company name from "FairCycle" to "Fimboo". This idea developed as the entrepreneur was thinking about what he could produce with the resources he already owns and has experience with, namely the bamboo and plastic components. Skiing and hiking poles could be a way to solve the challenges of scalability and customer focus in the European market. Within this new prototyping phase, the technical development of the poles remained with the entrepreneur and his technical advisors and took a substantial amount of time. The new product had to be designed from the ground up. Thereby, he utilized the material and technical resources he had accumulated in the previous phase. 


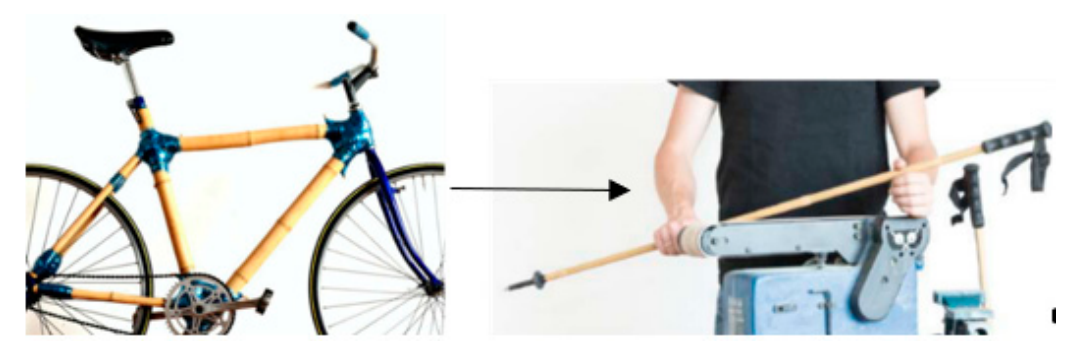

Figure 5. Product focus shift from the bicycle (left) to skiing poles (right).

Although development was perceived to be easier than the bicycles overall, first prototypes needed careful preparation. He started to rearrange his personal networks, which allowed him to avoid extensive costs. To use his already available resources, the poles should be made of bamboo while recycled plastic should be the foundation for the tips and handles. He aimed to recycle and reuse plastic waste within his company, but to achieve this, new technological assets were needed. Simon reported that the Netherlands has a considerable community with expertise in plastic waste management. Together with a Dutch community hub and their open source technology, he developed a plastic machine that turns plastic waste into granulate, which can then be melted and brought into form per injecting molding techniques and the respective templates. This machine, which he named "ultimate injection", turned out to be a core asset to produce the skiing and hiking poles.

Additionally, Simon facilitated networks with distribution partners already integrated into his business model's value exchange, which are aligned with his sustainable aspirations but also appealed to young and athletic customers. He further produced short video clips promoting his skiing poles in a contemporary manner, laying the focus on the sport and not on the positive environmental and social impact the products convey. Simon again applied to the accelerator and gained access to the program, as well as financial capital and the know-how of the incubator's employees. In addition, he applied and received grants from other funding authorities, who were supportive of his new product. In this phase, Simon often struggled with himself while implementing the changes, because he felt like he had partly given up on his environmental and social aims in favor of commercial viability and funding.

\subsubsection{Business Model Outcome}

According to the newly salient demands and guiding principles of profitability and scalability, which led to the new formation of goals and practices before and along the accelerator program, the business model changed in a radical manner.

The value proposition transformed dramatically, and the entrepreneur had to make compromises in relation to his environmental and social mission. In contrast to his earlier version, the social aspect and the positive effects on the communities in Uganda shifted to a more customer-focused value proposition, where the utility of the product for the customer came to the fore. The potential value in offering free mobility for citizens in Uganda gave way to an environmentally-friendly lifestyle product for the European customer. Yet, the value of employment and fairly paid jobs in Uganda remained as an integral part of the proposition. Additionally, the product offers a greener alternative to comparable products (e.g., carbon skiing poles) in the sports industry with lower negative effects on the environment.

The financial value capture is similar to the initial conception as it included the sale of the product in Europe, but the additional funding through a donation system was scratched. Furthermore, the entrepreneur adhered to his notion of social value capture through job creation and fair payment in Uganda and the environmental value of $\mathrm{CO}_{2}$-reduced production that saves energy and involves the recycling of plastic waste. However, because of the product change towards skiing poles, he had to compromise the social value of mobility in developing countries for potential financial scalability. The social value captured is not realized through the product anymore, but still remains through the value creation of creating and maintaining well-paid jobs in Uganda. 
To create value, the refined machines and newly developed templates for 3D printing were shipped to the employees in Uganda, who produced the poles. Plastic waste was collected and processed in Uganda. Although the product changed, the entrepreneur managed to maintain the established value creation.

By implementing the new goal of a scalable and more profitable venture, communication and distribution channels of the value exchange were enhanced. Simon now started to communicate the venture not only over the environmental and social significance but also through the notions of lifestyle and fun. Due to the new product, he was also able to acquire new distribution channels in the form of sustainable sports shops.

\subsection{Transition Phase 2: Industrial Logic}

\subsubsection{Trigger Induces Perceived Shift in Logic Salience}

After settling with the new product idea, first prototypes, and corresponding changes to the business model, another logic became salient, influencing the venture development. Before the entrepreneur could start with the final production of the ski poles, he engaged with and learned about the standardized norms of industrial production developed for the branch of sports equipment. Attending a workshop about this topic, Simon got a first glimpse of the required ISO norms and legal necessities from a certification consultant.

This phase is characterized by a rise of the logic of industrial production, which entails the aim for technical sophistication and high quality of products symbolized through certificates and anchored in international norms [75]. Through contact and interaction with certification consultants, testing authorities and legal texts, the latent guiding criteria of the industrial logic, namely efficiency, quality, and safety, became more central for the entrepreneur.

\subsubsection{Processing the Shift in Logic Salience}

Through contact with testing authorities and getting to know legal requirements aiming to provide a common foundation to guarantee safety, quality, and efficient production in the sports industry, the entrepreneur engaged with the logic of industrial production. In the interviews, our participants stated Simon's wish to have a product he can vouch for and fulfilling the quality demands prescribed by the industrial logic seemed one way to achieve this:

"When I enter the market with the new product, I don't just want to throw out something for one winter season. If I enter, it is supposed to be a decent product. All or nothing, so to speak". (Simon)

Here, a tension between his environmental aspirations and the new industrial logic emerged. He noted his worries concerning the realization of the norms with the environmentally sustainable material he used. Specifically, the bamboo in question was compared to the carbon of other manufacturers. A homogenous and standardized norm with natural materials, which have different breaking points depending on how the bamboo grows, seemed to be a difficult project. Yet, following his "all or nothing" approach, Simon was determined, because his interpretation of the industrial requirements was a natural fit with his own embodied values of social welfare.

Besides being obligated to offer a safe product to his customers, Simon saw the potential to achieve the certification as a symbol of quality when he evaluated the demands. Market research revealed that competitors could not meet the required standards. Therefore, fulfilling quality criteria, he stated, could give him a competitive edge. He further talked about potential liability issues that would emerge if he could not manage to sort out the technical requirements of testing authorities.

The demands of the industrial logic conflicted with the environmental aspiration of the entrepreneur in terms of his wish to use natural, regional, and recycled materials. However, after 
interpreting and evaluating the future impact, Simon saw more advantages than downsides and managed to construct a coherence between the current situation and the new logic.

\subsubsection{Personal Reorientation and Change Implementation}

The prominence of the logic of industrial production and the decision to follow its demands changed the trajectory of the entrepreneur's actions. As opposed to the influence of commercial logic, the entrepreneur easily complied with the new logic and committed to fulfilling the demands, taking it as a personal obligation. Simon formed new goals to achieve in this specific phase, aiming to refine his product so that it meets the specifications of legal texts and testing authorities. Thus, his overarching goal was to implement the quality and safety standards in his venture to attain the corresponding certificates from the testing authorities.

Simon's commitment to fulfilling the standards resulted in tedious efforts involved in finding the right authorities and ascertaining how the norms should be interpreted and implemented in his specific product.

"It took me almost a year until I landed at the right norm authority, which could test my product. [ ... ] One has to wait three weeks for an answer and when you write back to them it takes another three weeks until it is forwarded to the right person. [ ... ] It was like this for months until I finally got the right guy and then he tells me that he can't help me with the development". (Simon)

This experience with the testing authorities resulted in a pursuit of the norm requirements by testing the products by himself. For that, he aimed to build his own testing machine, which would assess the bamboo in terms of stability. Together with his friend, who also helped him to build the plastic machine "ultimate injection", he gained access to local maker spaces that provided the right tools for the task. To comply with the standards, the templates of the handles and tips of the skiing poles also needed a redesign, which he outsourced to a company specialized in industrial design.

With the new machine, he nearly tested 200 ski poles until he got a satisfying result. Further, he assessed competitive products and found that bamboo was even sturdier than other skiing poles made from carbon. Simon was sure that he could finally start the production on a larger scale.

A few weeks later, however, his optimism was suddenly shattered when he conducted further tests under more realistic conditions in skiing resorts. Indeed, the bamboo did not seem to be a problem, but the plastic turned out to be one. The sub-zero temperatures affected the recycled plastic, which had been collected, melted, and formed with the plastic machines in Uganda. The collected plastic in Uganda is different than in Europe and it turns brittle when exposed to cold weather. Thus, it was not feasible to use this material for the handles of the skiing poles and in turn not possible to adhere to the guiding principles of the logic of industrial production. Yet, incorporating workers in Uganda was still the main impact he aimed to create, and using other forms of plastic collection and production was not an alternative in this regard. His initial worries about the incompatibility of his natural and recycled materials and the demands of the industry had come true.

Not being able to fulfill the demands of efficiency, quality, and safety led to an emotional cut with the idea of skiing poles. Simon was not content to enter the market without this prerequisite:

"This is where his entrepreneurship differs from the profit-oriented 'I throw 2000 ski poles into the market and see what happens' to 'I want to sell a product that is good and durable and offers a certain level of security.'" (Martha)

Simon then had another idea. From now on he would focus on the "ultimate injection" machines he had developed. Until now, these machines would have been used to produce the handles of the skiing and hiking poles, but with different templates, the plastic could be formed into a multitude of other products, for example, frames for glasses. Putting together his bicycle and skiing pole projects, he found the common ground in the plastic component, which seemed to be the next logical step in the 
development of his business. Furthermore, the plastic machines already fulfilled the requirements of the industrial logic. Following this idea, he again changed the name of his entrepreneurial endeavors and because he aimed to focus on the plastic component, "Plasticpreneur" appeared to be a fitting name.

"That was the bamboo bicycle made of bamboo and recycled plastic bottles with which I have been immersed in this world and from which the 'Plasticpreneur' emerged. First a bamboo bicycle, where the bamboo was in the focus, then the skiing poles, again with the bamboo. Yet, actually, in both projects, the plastic component is even more substantial and entails the whole know-how we have built". (Simon)

Reorienting towards the producing and selling the plastic machines seemed like quite a stretch at first, but everything he needed for this shift of focus was already available to the entrepreneur. Simon utilized his networks embedded in his current business model (the industrial designer, contacts to the plastic recycling community in the Netherlands), which he had established in his earlier entrepreneurial process as well as the technological developments of the plastic machines and the know-how he gained in the product development of the bikes and skiing poles. In this way, Simon was able to integrate and use his stock of resources and circumvent the tensions of sustainable materials within the sports industry, which he could not fulfill in the light of his disposition and preferences. Simon stated that the experience he collected through his earlier projects made it possible to implement his new idea into his venture. This transition phase entails the product shift from skiing poles to the production machines and tools as shown in Figure 6.

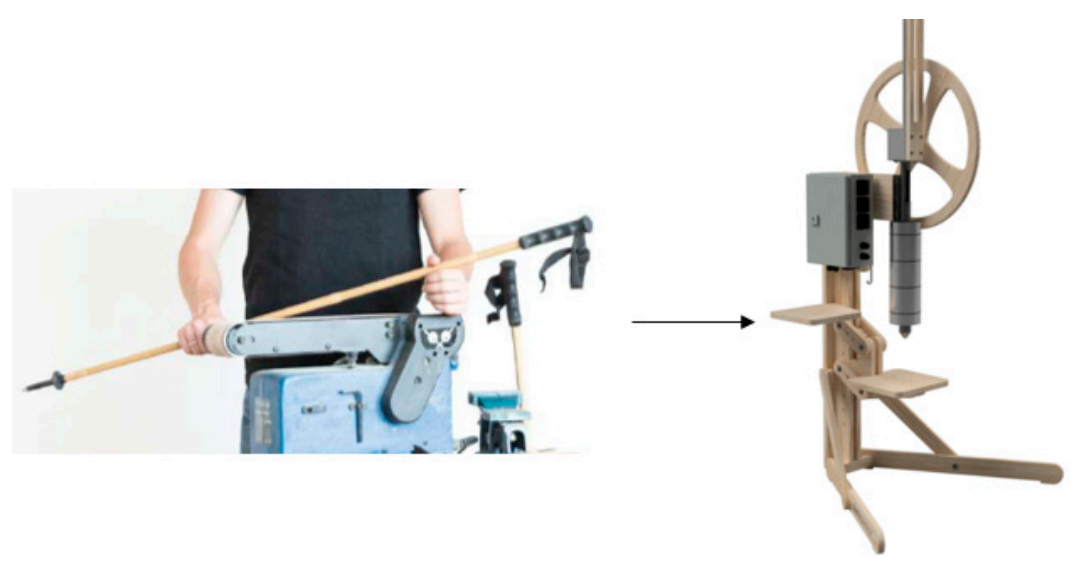

Figure 6. Product focus shift from the skiing poles (left) to the plastic machine (right).

Through his established networks, he was able to sell first plastic machines to new customers and with the accumulated resources he developed a new business model, adding a service aspect.

\subsubsection{Business Model Outcome}

Being unable to adhere to the guiding principles of the industrial logic with his product idea of skiing poles led to radical changes of the business model. This change is signified by the shift from a sports equipment manufacturer towards the production of machines and tools to recycle and reuse plastic waste for prototyping and production purposes.

Through the replacement of his core product of sports equipment, the value proposition and target groups were reevaluated. The new main target groups of his product are small and medium enterprises that use the plastic recycling tool kits to produce their own prototypes and products (e.g., frames for sunglasses, parts for bicycles, rain gutters, etc.) in an ecological way. Sports enthusiasts as customers, thus, were replaced by a completely different audience and so has the value that is offered for the specific target groups. Yet, the social values of employment, empowerment, and education for communities in Uganda have been kept as a core contribution and a manifestation of the entrepreneur's 
embodied dispositions into the value proposition. In addition, Simon's networking practices led to the cooperation with an Austrian university where he uses his tools in workshops to educate young people in terms of closed-loop plastic usage, sustainable life-cycle production, and business development.

Environmental value in the form of $\mathrm{CO}_{2}$ reduction is still an important part of the value capture as well as the social value in the form of employment and education. With the new business model, the entrepreneur also focuses on the creation of awareness for pupils and students as a new indicator for his environmental and social value capture. From a financial point of view, income is now generated through the sale of the plastic machines and tool kits for prototyping. Furthermore, Simon and his network of industrial designers offer additional services and guides for product template development and explain how the plastic machine can be used and integrated within such a process.

As opposed to the sports equipment, which was produced in Uganda by local citizens, a part of the value creation has been shifted to Austria, where the plastic machines are produced with regional woods and metal. The additional services for product development and machine usage are offered by the entrepreneur and his network of industrial designers. To create the environmental (creating awareness of environmental problems) and social value of education, Simon works with an Austrian university to conduct the workshops. Uganda is still involved in this process, as his employees utilize the plastic machines to independently produce different goods for their local market and revenues of these activities are reinvested in the community. Overall, he was able to enhance his business model in this regard, building on a wider and more integrated network for value creation in different dimensions.

For the value exchange, the communication of the fun and lifestyle product has been scratched instead, the entrepreneur aims to communicate his plastic machines, tools, and services for sustainable production purposes. Environmental and social sustainability still lies at the heart of his communication approach when interacting with customers and stakeholders, but he could not find a replacement for the distribution channel of niche markets from his earlier ideas. His own web-shop is, thus, the main distribution channel.

A summary of the different business models including the initial version and two versions after the business model changes is given in Table 3 . 
Table 3. Summary of business model transitions.

\begin{tabular}{|c|c|c|c|}
\hline & Initial Business Model & Business Model after the First Transition & Business Model after the Second Transition \\
\hline $\begin{array}{l}\text { Dominant institutional logic integrated } \\
\text { into the business model }\end{array}$ & $\begin{array}{l}\text { Internalized environmental logic and social welfare } \\
\text { logic (Habitus) }\end{array}$ & Commercial market logic & Industrial production logic \\
\hline Targeted business image & Social change-maker & Sustainable sports equipment provider & Experts in plastic recycling and product development \\
\hline Company name & FairCycle & Fimboo & Plasticpreneur \\
\hline Product focus & Bicycles & Skiing and hiking poles & Plastic machines "ultimate injection" \\
\hline Value proposition & $\begin{array}{l}\text { Free mobility for communities in Uganda } \\
\text { Alternative bike for sustainable consumers }\end{array}$ & $\begin{array}{l}\text { Compromise } \\
\text { Lifestyle product for sustainable sports enthusiasts } \\
\text { Sustainable branded products for ski regions } \\
\text { Employment and education for communities in Uganda }\end{array}$ & $\begin{array}{l}\text { Replacement } \\
\text { Employment and education for communities in Uganda } \\
\text { Plastic machines for rapid prototyping and production for small and } \\
\text { medium enterprises } \\
\text { Workshops (education) about the closed-loop plastic economy in } \\
\text { Austria }\end{array}$ \\
\hline Value capture & $\begin{array}{c}\text { Mobility } \\
\text { Employment and education } \\
\mathrm{CO}_{2} \text { and waste reduction } \\
\text { Revenue through selling skiing poles } \\
\text { Donations }\end{array}$ & $\begin{array}{c}\text { Compromise } \\
\text { Employment and education } \\
\mathrm{CO}_{2} \text { and waste reduction } \\
\text { Revenue through selling skiing poles }\end{array}$ & $\begin{array}{c}\text { Enhancement } \\
\text { Employment and education } \\
\mathrm{CO}_{2} \text { and waste reduction } \\
\text { Creating awareness for environmental challenges } \\
\text { Revenue through selling plastic machines }\end{array}$ \\
\hline Value exchange & $\begin{array}{l}\text { Communicate environmental components and social } \\
\text { production and } \\
\text { Main distribution channel online-shop }\end{array}$ & $\begin{array}{c}\text { Enhancement } \\
\text { Communicate environmental components and social production and } \\
\text { Distribution in niche sports shops } \\
\text { Communicate Lifestyle and fun } \\
\text { Main distribution channel online-shop }\end{array}$ & $\begin{array}{l}\text { Replacement } \\
\text { Communicate environmental components and social production } \\
\text { Communicate tools for environmental production } \\
\text { Main distribution channel online-shop }\end{array}$ \\
\hline Value creation & $\begin{array}{l}\text { Bicycles are produced in Uganda with local and } \\
\text { recycled materials } \\
\text { Skiing poles are sold in Europe } \\
\text { Revenues are reinvested in projects in Uganda }\end{array}$ & $\begin{array}{c}\text { Maintenance } \\
\text { Skiing poles are produced in Uganda with local and recycled materials } \\
\text { Skiing poles are sold in Europe } \\
\text { Revenues are reinvested in projects in Uganda }\end{array}$ & $\begin{array}{c}\text { Enhancement } \\
\text { Plastic machines are produced in Austria } \\
\text { Product development services for small and medium enterprises } \\
\text { Revenues are reinvested in projects in Uganda } \\
\text { Workshops in Austria together with universities }\end{array}$ \\
\hline
\end{tabular}

Note: Bold text denotes business model additions due to the transition phase. 


\section{Discussion}

Our research set out to explore (1) how sustainable entrepreneurs experience multiple institutional logics while they develop their business and (2) how they integrate the associated values into a coherent business model. We add to this by deriving a novel process model of business model transitions under conditions of multiple logics (Figure 4). In the following, we discuss our findings along the theoretical model and in relation to the initially posed research questions as well as current literature.

\subsection{Experiencing Multiple Institutional Logics_Processing a Shift in Logic Salience and the Role of Habitus}

The study provided us with numerous new insights on how entrepreneurs experience multiple logics and their associated values, beliefs, and guiding principles. Following recently raised questions on how certain logics become more salient than others in sustainability-oriented forms of entrepreneurship [18], we can contribute that sustainable entrepreneurs experience institutional logics through social interaction with a multitude of potential stakeholders and legal industry-dependent specifications (e.g., legal texts) in their venturing process, where demands, values, and guiding principles of other logics are articulated. This puts them in a position where they reflect on how to deal with such demands. In sustainable entrepreneurship, logics are not always perceived to the same degree. They change in terms of the importance the individual entrepreneur attributes to them. For example, the logics of industrial production did not seem to influence the process of business modeling until the demands of the standards became acute as a result of approaching market maturity with the product. This means that there are a multitude of potential latent logics that only get activated if the entrepreneur experiences them as important. This is in line with research positing that sustainable entrepreneurs are not detachable from their institutional environment [83].

We add to the call to consider the relationship between institutional logics and organizational change and its underlying mechanisms constituted by individuals' actions [76]. Specifically, we reveal the connection between the sustainable entrepreneurs' habitus, the multiple logics and the change processes of business models over time [24]. Current theoretical deliberations are enlightening, but have not experienced a contextualized application in an empirical setting $[14,21]$. The study provides insights into the importance of the entrepreneurs' habitus in processing the shift of logic salience. Habitus entails the cognitive structures that actors use to make sense of their situation within a field [84]. In our case of sustainable entrepreneurship, these cognitive structures emerged from the previous experiences of social welfare, environmental protection work, and cultural embeddedness in religious structures and point towards the internalization of preferences, dispositions, and aspirations influenced by environmental and social logics. Actors are more 'fluent' in their embodied logics, making them more likely to orient their actions according to the internalized logics, even if they know the alternatives $[85,86]$. We argue that the logic internalized within the habitus of the entrepreneur provide the foundation to interpret the newly appearing guiding principles and act as a space where coherence between internalized dispositions and more unfamiliar logics is formed. Data shows that after the trigger, the entrepreneur started to interpret the demands of the new logics filtered through the habitus and, from then on, he evaluated the demands compared to the individual preferences and aspirations. While other work also provides information on the reflexivity of the entrepreneur in the process of venture legitimization [20], our study offers additional insights on how sustainable entrepreneurs can use the ample room for interpretation provided by the demands to construct coherence with the individual's own preferences and aspirations as well as the further contextual factors embedding the transition phase.

Additionally, the current business model and the change-specific logic interplay in processing the shift in logic salience. The current business model provides a pre-built structure that incorporates already materialized ways of value creation, exchange, and capture that naturally influences the interpretation and the act of establishing a cognitive coherence between the guiding principles and the current situation. In this spirit, prospective sensemaking- "the conscious and intentional consideration of the probable future impact of certain action" [87] —appeared to be an important 
mechanism for the entrepreneur to make sense of the new demands and the potential outcomes of adhering to them. Recently, this future-oriented way of making sense of new demands has gained attention in organizations research [88] and warrants further integration in the studies of sustainable entrepreneurship.

\subsection{Integrating and Blending Multiple Institutional Logics-Reorientation, Change Implementation and Business Model Outcomes}

Another main point for discussion is how the entrepreneur implemented the multiple logics within the business model. In this regard, findings show how sustainable entrepreneurs engage in a personal reorientation according to the new change-specific dominant logic. Current research remarks on the potential impact of differentiated commitments to institutional logics on the business models of organizations [21]. We add to this by showing that sustainable entrepreneurs have options in the degree of commitment to the newly salient logics depending on their interpretation of the new guiding principles. For example, data provide information on a form of commitment where obliging to the new guiding principles of the commercial market serves as a means to achieve the entrepreneur's ends to create environmental and social impact. In other words, the entrepreneur tried to develop a scalable product but did not, in fact, plan to scale with his business. He merely aimed to meet the requirements for potential funding. According to scholarly discussions, sustainable entrepreneurs use their profit to achieve their ecological and social objectives [15]. Expanding our knowledge in this regard, our research shows that they might also instrumentalize the symbolic effect of the commercial logic to gain access to financial funding. In the second transition phase, the entrepreneur experienced potential conflicts of demands of the industrial logic and its implementation in the context of his environmental aspirations. However, Simon was still able to fully comply with those demands as they resonated with his own values and his desire to be identified with the required quality and safety principles of the industrial logic. This commitment has been characterized by a feeling of personal obligation (although he was not able to adhere to these principles in the end). We thus propose that the type of commitment is important in the subsequent development of the transition phase, as the case implies that new goals and practices mirror the type of commitment towards the newly salient logic.

The implementation of the change is carried out in the context of the pre-change business model configuration, were already available resources and networks embedded in the previous version of the business model are re-purposed. In that sense, the pre-change business model acts as a stock of resources or repertoire to the entrepreneur that can be utilized to implement the institutionalized demands. This behavior points towards the notion of bricolage [89,90], which allowed for the re-arrangement of available material resources and networks into new configurations of the business models that then reflect the emerged institutional logics. To illustrate this, we refer to the first transition phase where the entrepreneur took available materials of plastic and bamboo (and his corresponding knowledge about these materials) and transformed them into a new product through prototyping. Also, transition phase 2 provides a similar path of experimental action, where available technology used in the previous value creation (i.e., the plastic machine) is refined and put into the focus of the business model. This complements research on entrepreneurship that portrays entrepreneurs as creative agents who create new outcomes with available resources [90].

Further, in engaging with new practices to carry out the transition, the entrepreneur was confronted with implementation challenges. While engaging with the new practices, the entrepreneur experienced tensions between his internalized environmental and social logic (his habitus) and the commercial as well as industrial logic. While implementing the demands of the commercial logic was rather uncomplicated and the feeling of giving up one's own values could be resolved, the conflict between the industrial logic and Simon's environmental aims was irresolvable. The products' environmental materials (recycled plastic) were not compatible with the guiding principles of the industrial logic leading to yet another product focus shift through which these demands could be fulfilled. Adding to research on logic-related tensions within sustainable entrepreneurship $[7,8,23]$, we argue that dividing 
between resolvable und irresolvable tensions on a personal level appears to be important when analyzing reactions to such tensions.

Finally, these transition phases are reflected within the business model, leading to a new temporary settlement of the venture [76]. We provide insights into how the entrepreneur had to compromise and replace functions of the business model components, depending on the change process and how he could maintain and enhance others. Thus, findings go beyond the theoretically proposed tensions and complementarities of sustainable business models [14] and show distinct outcomes of enhancement, replacement, compromise, and maintenance of individual components, which allow for a more fine-grained analysis of the influence of multiple logics. The change in the business model was accompanied by the entrepreneur's aim to develop another business image-from a social change-maker towards an environmentally-friendly sports equipment provider to a plastic-recycling expert.

Notably, the value proposition and value capture are closely related in sustainable ventures and we found expected tensions between the social welfare and market logic leading to compromises in that regard [13]. Nevertheless, adhering to the commercial market logic also resulted in an enhancement of the value exchange, extending the distribution channels and the possibilities for communicating the environmental and social value. Similarly, the transition phase guided by the industrial logic allowed him to enhance his reach in terms of awareness-building through the availability of new networks such as universities. This offered the entrepreneur novel ways to enact his embodied environmental and social dispositions and in turn, create and capture sustainability-related values. Business model outcomes altering business model components and functions, thus, constitute complex trade-offs of competing institutionalized values and beliefs. In our case, and due to the intertwined and complex nature of the business models $[29,51,91]$, a shift of logic salience led to tremendous alterations of the business model. However, in the light of the entrepreneur's aspirations, values, and beliefs, and through his interpretations and behavior, the entrepreneur managed to selectively integrate these logics while keeping his main mission of sustainability intact. This leads us to the conclusion that answering the question of how sustainable entrepreneurs experience and blend multiple logics into their business models is dependent on the interpretations, orientation, and change implementation of the entrepreneur. Here, we especially stress the importance of the contextual factors including the entrepreneurs' habitus and business model acting as pre-defined structures to the change process. Hence, we propose that habitus and the business model lens can provide ways to contextualize change processes of sustainable ventures.

\section{Implications}

This study significantly contributes to current research in numerous ways. We follow the call for more in-depth accounts of entrepreneurs actions in creating value for sustainability under potential institutional tensions $[7,9,15]$. We inductively derived an original theoretical model that offers a foundation to make sense of the complex actions and business model outcomes of entrepreneurs' efforts to create various forms of value. By empirically investigating this phenomenon, we go beyond recently posited theoretical elaborations $[14,21]$ and unpack business model transitions offering crucial insights and expand previous findings. We add to recent research [18] by discussing how a shift in logic salience occurs and is processed by the entrepreneur while developing a business. Further, our study expands on past work, for instance $[9,14,44]$, and discusses how entrepreneurs engage in personal reorientation and implement business model changes through concrete actions.

Moreover, we especially emphasize the previously unexplored theoretical concepts identified to contextualize the business model transition. To the best of our knowledge, this is the first empirical study that discusses the role of habitus in dealing with contradictory institutional logics along a business modeling process. With that, we contribute to the recent theoretical work on institutional logics [85] by providing an empirically grounded exploration of the importance of habitus to understand entrepreneurs' attachment to different logics and its effect on the orientation towards specific entrepreneurial actions. 
The results of our research also add to the business model literature. Our application of the componential approach to business models [14] allowed for an in-depth portrayal of change processes and complex trade-offs of business model configurations. Recent work on sustainable business models operates under the assumption that the creation of environmental, social, and economic value manifest in the form of tensions [13]. Our detailed analysis, however, revealed that following new guiding principles led to tensions and opportunities at the same time where compromises in one business model component led to enhancement in others. This has profound theoretical implications for the analysis of the development of sustainable business models. We argue that a static and dichotomous view of tensions within business models is not expedient due to the interrelatedness and complexity of business model components $[29,51,91]$. Consequently, we advocate that researchers need to take these complex interrelations into account.

The study holds also holds practical implications for sustainable entrepreneurs as well as public actors such as grant providers or incubators. For entrepreneurs, we argue that dealing with new and unfamiliar logics and the integration of new guiding principles into their business model can entail wide-ranging changes, heavily influencing the trajectory of the business. Keeping this in mind can help to deal with new demands. Our case offers a learning opportunity here: through the conscious engagement with potential tensions and its future effects, the sustainable entrepreneur was able to find a fit between the new logics and his current ambitions and business model. A creative interpretation of the new demands in relation to the current situation can be supportive when it comes to achieving a satisfying basis to make subsequent decisions and actions, which can maintain or even enhance business model functions with importance to the entrepreneur. Entrepreneurs can use the findings of this paper to identify potential pitfalls in creating multiple forms of value within their business. The theoretical model offers a foundation for entrepreneurs to think about ways to approach this challenge.

In our case, we also identified the significant impact of grant systems, legal text interpretations, and incubators as a source for a shift in dominant logics in the early entrepreneurial process. Such supporting organizations follow their own logics, which is still dominated by a commercial approach. Nevertheless, more tailored grants and accelerator programs that understand and appreciate the entrepreneurs' environmental and social ambitions, and that are aware of the potential tensions and subsequent effects. Dealing with changes of the business to comply with multiple institutions must not be a one-way street and a burden for the entrepreneur only. Advisors from incubators or funding authorities can support sustainable entrepreneurs in these phases of change and help them to interpret and translate new guiding principles in the light of the current business and the entrepreneurs' mission. To successfully support sustainable entrepreneurs, and to facilitate their social and environmental impact, rethinking business incubators so that they transform from a mere source of change into a more supporting factor along the change process, is one way to start. Policy makers or business incubators can use our case study and especially the derived theoretical model to create awareness of the complex interrelation of the entrepreneurs' aspirations and goals and the respective business model.

\section{Limitations and Future Research}

Our study has certain limitations. We utilized a longitudinal single case study design to follow current calls for a more in-depth analysis of institutional logics in entrepreneurship and business modeling $[15,24]$. Although our case, like every case, has some particularities, we argue that the derived model is transferable to other contexts and cases, especially in alternative forms of entrepreneurship, which are theorized to be influenced by multiple logics, almost per definition $[7,14,20]$. We collected data in the early phases of the venture development when entrepreneurs engage different logics for the first time. We found this phase to be especially revealing in how sustainable entrepreneurs approach new logics [92], but other phases of the entrepreneurial process may play out differently [71]. We, thus, encourage future research to transfer our theoretical framework into other contexts for further development and revision. Future work can, thus, utilize our framework and the investigated concepts to elucidate business model transitions in numerous entrepreneurial contexts. This will 
allow us to unravel the complex social and cultural processes, which are of utter importance in entrepreneurial venturing.

Our work also opens several other areas for future research. For instance, scholars might investigate in which form sustainable entrepreneurs commit to and identify with newly emerging guiding principles. How does the commitment of the entrepreneur differ due to individual aspirations and goals? How does the commitment to distinct logics change over time and how does it influence the value creation? Additionally, larger scale research is needed in this regard. Furthermore, it would be of interest to investigate how sustainable entrepreneurs instrumentalize the symbolic effect of the commercial market logic for their purposes as hinted in our case.

In our inductive approach to investigating the business modeling under conditions of multiple logics, we found the behavior of the entrepreneur references behavioral patterns identified in the entrepreneurship literature. The entrepreneur engaged in resource and network rearrangements similar to entrepreneurial bricolage [90]. By using already available resources, materials, and networks, the entrepreneur was able to reconfigure his business model to meet the demands of the new guiding principles. We argue that bricolage can cross-fertilize the research on institutional logics and sustainable entrepreneurs in conjunction with business model innovation and we propose that further engagement with this topic is warranted in future research. Scholars could, for example, use our exploratory findings to investigate how the pre-defined structure of a business model hinder or facilitate changes to the venture, and how entrepreneurs leverage the already available resources and networks to establish new business model versions.

Author Contributions: Conceptualization, P.G., M.A.W. and E.J.S.; Formal analysis, P.G.; Methodology, P.G.; Project administration, M.A.W. and E.J.S.; Supervision, M.A.W., E.J.S. and P.H.; Writing-Original Draft, P.G.; Writing—Review \& Editing, P.G., P.H., E.J.S.

Funding: This research was funded by the Österreichische Nationalbank (ÖNB-Application Number 16735).

Acknowledgments: The authors would like to thank the editor and anonymous reviewers for their constructive feedback and helpful suggestions.

Conflicts of Interest: The authors declare no conflict of interest.

\section{References}

1. Eichler, G.; Schwarz, E. What Sustainable Development Goals Do Social Innovations Address? A Systematic Review and Content Analysis of Social Innovation Literature. Sustainability 2019, 11, 522. [CrossRef]

2. Dixon, S.E.A.; Clifford, A. Ecopreneurship - a new approach to managing the triple bottom line. J. Organ. Chang. Manag. 2007, 20, 326-345. [CrossRef]

3. Shepherd, D.A.; Patzelt, H. The New Field of Sustainable Entrepreneurship: Studying Entrepreneurial Action Linking "What Is to Be Sustained" with “What Is to Be Developed". Entrep. Theory Pract. 2011, 35, 137-163. [CrossRef]

4. McMullen, J.S.; Warnick, B.J. Should We Require Every New Venture to Be a Hybrid Organization? J. Manag. Stud. 2016, 53, 630-662. [CrossRef]

5. Hall, J.K.; Daneke, G.A.; Lenox, M.J. Sustainable development and entrepreneurship: Past contributions and future directions. J. Bus. Ventur. 2010, 25, 439-448. [CrossRef]

6. Muñoz, P.; Dimov, D. The call of the whole in understanding the development of sustainable ventures. J. Bus. Ventur. 2015, 30, 632-654. [CrossRef]

7. York, J.G.; O'Neil, I.; Sarasvathy, S.D. Exploring Environmental Entrepreneurship: Identity Coupling, Venture Goals, and Stakeholder Incentives. J. Manag. Stud. 2016, 53, 695-737. [CrossRef]

8. DiVito, L.; Bohnsack, R. Entrepreneurial orientation and its effect on sustainability decision tradeoffs: The case of sustainable fashion firms. J. Bus. Ventur. 2017, 32, 569-587. [CrossRef]

9. De Clercq, D.; Voronov, M. Sustainability in entrepreneurship: A tale of two logics. Int. Small Bus. J. 2011, 29, 322-344. [CrossRef]

10. Dufays, F.; Huybrechts, B. Where do hybrids come from? Entrepreneurial team heterogeneity as an avenue for the emergence of hybrid organizations. Int. Small Bus. J. 2016, 34, 777-796. [CrossRef] 
11. Belz, F.M.; Binder, J.K. Sustainable Entrepreneurship: A Convergent Process Model. Bus. Strateg. Environ. 2015, 26, 1-17. [CrossRef]

12. Jolink, A.; Niesten, E. Sustainable Development and Business Models of Entrepreneurs in the Organic Food Industry. Bus. Strateg. Environ. 2015, 24, 386-401. [CrossRef]

13. Davies, I.A.; Chambers, L. Integrating hybridity and business model theory in sustainable entrepreneurship. J. Clean. Prod. 2018, 177, 378-386. [CrossRef]

14. Laasch, O. Beyond the purely commercial business model: Organizational value logics and the heterogeneity of sustainability business models. Long Range Plann. 2018, 51, 158-183. [CrossRef]

15. Stubbs, W. Sustainable Entrepreneurship and B Corps. Bus. Strateg. Environ. 2017, 26, 331-344. [CrossRef]

16. Wry, T.; York, J.G. An Identity-Based Approach to Social Enterprise. Acad. Manag. Rev. 2017, 42, 437-460. [CrossRef]

17. Langley, D.J.; Zirngiebl, M.; Sbeih, J.; Devoldere, B. Trajectories to reconcile sharing and commercialization in the maker movement. Bus. Horiz. 2017, 60, 783-794. [CrossRef]

18. Cherrier, H.; Goswami, P.; Ray, S. Social entrepreneurship: Creating value in the context of institutional complexity. J. Bus. Res. 2018, 86, 245-258. [CrossRef]

19. Thornton, P.H.; Ocasio, W.; Lounsbury, M. The Institutional Logics Perspective: A New Approach to Culture, Structure, and Process; Oxford University Press: Oxford, UK, 2012.

20. O'Neil, I.; Ucbasaran, D. Balancing "what matters to me" with "what matters to them": Exploring the legitimation process of environmental entrepreneurs. J. Bus. Ventur. 2016, 31, 133-152. [CrossRef]

21. Ocasio, W.; Radoynovska, N. Strategy and commitments to institutional logics: Organizational heterogeneity in business models and governance. Strateg. Organ. 2016, 14, 287-309. [CrossRef]

22. Randles, S.; Laasch, O. Theorising the Normative Business Model. Organ. Environ. 2016, 29, 53-73. [CrossRef]

23. Battilana, J.; Sengul, M.; Pache, A.-C.; Model, J. Harnessing Productive Tensions in Hybrid Organizations: The Case of Work Integration Social Enterprises. Acad. Manag. J. 2015, 58, 1658-1685. [CrossRef]

24. Spieth, P.; Schneider, S.; Clauß, T.; Eichenberg, D. Value drivers of social businesses: A business model perspective. Long Range Plann. 2018. [CrossRef]

25. Thompson, N.A. Institutional Logics and Entrepreneurship: Struggling for Legitimacy in the Emerging Bioenergy Field. Ph.D. Thesis, Utrecht University, Utrecht, The Netherlands, 2013.

26. Westholz, A. Conventions and institutional logics: invitation to a dialogue between two theoretical approaches. In New Themes in Institutional Analysis: Topics and Issues from European Research; Krücken, G., Mazza, C., Meyer, R., Walgenbach, P., Eds.; Edward Elgar Publishing: Cheltenham, UK, 2017; pp. 77-103.

27. Friedland, R.; Alford, R.R. Bringing Society Back In: Symbols, Practices, and Institutional Contradictions. In The New Institutionalism in Organizational Analysis; DiMaggio, P.J., Powell, W.W., Eds.; The University of Chicago Press: Chicago, IL, USA, 1991; pp. 232-266.

28. Amit, R.; Zott, C. Value creation in E-business. Strateg. Manag. J. 2001, 22, 493-520. [CrossRef]

29. Teece, D.J. Business Models, Business Strategy and Innovation. Long Range Plann. 2010, 43, 172-194. [CrossRef]

30. Dalpiaz, E.; Rindova, V.; Ravasi, D. Combining Logics to Transform Organizational Agency. Adm. Sci. Q. 2016, 61, 347-392. [CrossRef]

31. Reay, T.; Jones, C. Qualitatively capturing institutional logics. Strateg. Organ. 2016, 14, 441-454. [CrossRef]

32. Gioia, D.A.; Corley, K.G.; Hamilton, A.L. Seeking Qualitative Rigor in Inductive Research. Organ. Res. Methods 2013, 16, 15-31. [CrossRef]

33. Glaser, B.G.; Strauss, A.L. The Discovery of Grounded Theory: Strategies for Qualitative Research; Reprint; AldineTransaction: New Brunswick, NJ, USA, 2006.

34. Langley, A. Strategies for Theorizing from Process Data. Acad. Manag. Rev. 1999, 24, 691. [CrossRef]

35. Thornton, P.H.; Ocasio, W.; Lounsbury, M. The Institutional Logics Perspective. In Emerging Trends in the Social and Behavioral Sciences; Scott, R., Kosslyn, S., Eds.; John Wiley \& Sons, Inc.: Hoboken, NJ, USA, 2015; pp. 1-22.

36. Thornton, P.H.; Ocasio, W. Institutional Logics and the Historical Contingency of Power in Organizations: Executive Succession in the Higher Education Publishing Industry, 1958- 1990. Am. J. Sociol. 1999, 105, 801-843. [CrossRef]

37. Friedland, R. Moving Institutional Logics Forward: Emotion and Meaningful Material Practice. Organ. Stud. 2018, 39, 515-542. [CrossRef] 
38. Hallett, T.; Ventresca, M.J. Inhabited Institutions: Social Interactions and Organizational Forms in Gouldner's Patterns of Industrial Bureaucracy. Theory Soc. 2006, 35, 213-236. [CrossRef]

39. Greenwood, R.; Raynard, M.; Kodeih, F.; Micelotta, E.R.; Lounsbury, M. Institutional Complexity and Organizational Responses. Acad. Manag. Ann. 2011, 5, 317-371. [CrossRef]

40. York, J.G.; Hargrave, T.J.; Pacheco, D.F. Converging Winds: Logic Hybridization in the Colorado Wind Energy Field. Acad. Manag. J. 2016, 59, 579-610. [CrossRef]

41. Dean, T.J.; McMullen, J.S. Toward a theory of sustainable entrepreneurship: Reducing environmental degradation through entrepreneurial action. J. Bus. Ventur. 2007, 22, 50-76. [CrossRef]

42. Cohen, B.; Winn, M.I. Market imperfections, opportunity and sustainable entrepreneurship. J. Bus. Ventur. 2007, 22, 29-49. [CrossRef]

43. Gast, J.; Gundolf, K.; Cesinger, B. Doing business in a green way: A systematic review of the ecological sustainability entrepreneurship literature and future research directions. J. Clean. Prod. 2017, 147, 44-56. [CrossRef]

44. Muñoz, P.; Cohen, B. Sustainable Entrepreneurship Research: Taking Stock and looking ahead. Bus. Strateg. Environ. 2017. [CrossRef]

45. Pacheco, D.F.; Dean, T.J.; Payne, D.S. Escaping the green prison: Entrepreneurship and the creation of opportunities for sustainable development. J. Bus. Ventur. 2010, 25, 464-480. [CrossRef]

46. Schaltegger, S.; Wagner, M. Sustainable entrepreneurship and sustainability innovation: categories and interactions. Bus. Strateg. Environ. 2011, 20, 222-237. [CrossRef]

47. Mars, M.M.; Lounsbury, M. Raging Against or With the Private Marketplace? J. Manag. Inq. 2009, 18, 4-13. [CrossRef]

48. Casadesus-Masanell, R.; Ricart, J.E. From Strategy to Business Models and onto Tactics. Long Range Plann. 2010, 43, 195-215. [CrossRef]

49. Zott, C.; Amit, R.; Massa, L. The Business Model: Recent Developments and Future Research. J. Manage. 2011, 37, 1019-1042. [CrossRef]

50. Massa, L.; Tucci, C.L.; Afuah, A. A Critical Assessment of Business Model Research. Acad. Manag. Ann. 2017, 11, 73-104. [CrossRef]

51. Abdelkafi, N.; Täuscher, K. Business Models for Sustainability From a System Dynamics Perspective. Organ. Environ. 2016, 29, 74-96. [CrossRef]

52. Biloslavo, R.; Bagnoli, C.; Edgar, D. An eco-critical perspective on business models: The value triangle as an approach to closing the sustainability gap. J. Clean. Prod. 2018, 174, 746-762. [CrossRef]

53. Osterwalder, A.; Pigneur, Y. Business model generation: a handbook for visionaries, game changers, and challengers; Wiley: Hoboken, NJ, USA, 2010.

54. Doherty, B.; Haugh, H.; Lyon, F. Social Enterprises as Hybrid Organizations: A Review and Research Agenda. Int. J. Manag. Rev. 2014, 16, 417-436. [CrossRef]

55. Lüdeke-Freund, F.; Dembek, K. Sustainable business model research and practice: Emerging field or passing fancy? J. Clean. Prod. 2017, 168, 1668-1678. [CrossRef]

56. Pinkse, J.; Groot, K. Sustainable Entrepreneurship and Corporate Political Activity: Overcoming Market Barriers in the Clean Energy Sector. Entrep. Theory Pract. 2015, 39, 633-654. [CrossRef]

57. Jabłoński, A.; Jabłoński, M. Research on Business Models in their Life Cycle. Sustainability 2016, 8, 430. [CrossRef]

58. Foss, N.J.; Saebi, T. Fifteen Years of Research on Business Model Innovation. J. Manage. 2017, 43, $200-227$. [CrossRef]

59. Holzmann, P.; Breitenecker, R.J.; Soomro, A.A.; Schwarz, E.J. User entrepreneur business models in 3D printing. J. Manuf. Technol. Manag. 2017, 28, 75-94. [CrossRef]

60. Bocken, N.M.P.; Short, S.W.; Rana, P.; Evans, S. A literature and practice review to develop sustainable business model archetypes. J. Clean. Prod. 2014, 65, 42-56. [CrossRef]

61. Boons, F.; Lüdeke-Freund, F. Business models for sustainable innovation: State-of-the-art and steps towards a research agenda. J. Clean. Prod. 2013, 45, 9-19. [CrossRef]

62. Zott, C.; Amit, R. Business Model Design: An Activity System Perspective. Long Range Plann. 2010, 43, 216-226. [CrossRef]

63. Zott, C.; Amit, R. Business Model Design and the Performance of Entrepreneurial Firms. Organ. Sci. 2007, 18, 181-199. [CrossRef] 
64. Villani, E.; Greco, L.; Phillips, N. Understanding Value Creation in Public-Private Partnerships: A Comparative Case Study. J. Manag. Stud. 2017, 54, 876-905. [CrossRef]

65. Täuscher, K.; Abdelkafi, N. Scalability and robustness of business models for sustainability: A simulation experiment. J. Clean. Prod. 2018, 170, 654-664. [CrossRef]

66. Yin, R.K. Validity and generalization in future case study evaluations. Evaluation 2013, 19, 321-332. [CrossRef]

67. Tracey, P.; Phillips, N.; Jarvis, O. Bridging Institutional Entrepreneurship and the Creation of New Organizational Forms: A Multilevel Model. Organ. Sci. 2011, 22, 60-80. [CrossRef]

68. Berglund, H. Researching entrepreneurship as lived experience. In Handbook of Qualitative Research Methods in Entrepreneurship; Neergaard, H., Ulhøi, P.J., Eds.; Edward Elgar Publishing: Cheltenham, UK, 2007; pp. 75-96.

69. Cope, J. Researching Entrepreneurship through Phenomenological Inquiry: Philosophical and Methodological Issues. Int. Small Bus. J. 2005, 23, 163-189. [CrossRef]

70. Yin, R.K. Case Study Research: Design and Methods; SAGE: Thousand Oaks, CA, USA, 2014.

71. Battilana, J.; Dorado, S. Building Sustainable Hybrid Organizations: The Case of Commercial Microfinance Organizations. Acad. Manag. J. 2010, 53, 1419-1440. [CrossRef]

72. Langley, A.; Abdallah, C. Templates and Turns in Qualitative Studies of Strategy and Management. In Building Methodological Bridges: Research Methodology in Strategy and Management; Bergh, D.D., Ketchen, D.J., Eds.; Emerald Group Publishing Limited: Bingley, UK, 2011; pp. 105-140.

73. True to the Faith: A Gospel Reference; The Church of Jesus Christ of Latter-Day Saints: Salt Lake City, UT, USA, 2004.

74. Thévenot, L.; Moody, M.; Lafaye, C. Forms of valuing nature: Arguments and modes of justification in French and American environmental disputes. In Rethinking Comparative Cultural Sociology: Repertoires of Evaluation in France and the United States (Cambridge Cultural Social Studies); Lamont, M., Thévenot, L., Eds.; Cambridge University Press: Cambridge, UK, 2000; pp. 229-272.

75. Boltanski, L.; Thévenot, L. On Justification: Economies of Worth; Princeton University Press: Princeton, NJ, USA, 2006.

76. Schildt, H.; Perkmann, M. Organizational Settlements. J. Manag. Inq. 2017, 26, 139-145. [CrossRef]

77. Bourdieu, P. The Logic of Practice; Stanford University Press: Stanford, CA, USA, 1990.

78. Bourdieu, P. The Forms of Capital. In Handbook of Theory and Research for the Sociology of Education; Richardson, J., Ed.; Greenwood: New York, NY, USA, 1986; pp. 241-258.

79. Bourdieu, P. Pascalian Meditations; Stanford University Press: Stanford, CA, USA, 2000.

80. Terjesen, S.; Elam, A. Transnational Entrepreneurs' Venture Internationalization Strategies: A Practice Theory Approach. Entrep. Theory Pract. 2009, 33, 1093-1120. [CrossRef]

81. Bourdieu, P. Outline of a Theory of Practice; Cambridge University Press: Cambridge, UK, 1977.

82. Outsios, G.; Kittler, M. The mindset of UK environmental entrepreneurs: A habitus perspective. Int. Small Bus. J. Res. Entrep. 2018, 36, 285-306. [CrossRef]

83. Thompson, N. Biofuels are (Not) the Future! Legitimation Strategies of Sustainable Ventures in Complex Institutional Environments. Sustainability 2018, 10, 1382. [CrossRef]

84. De Clercq, D.; Voronov, M. Toward a Practice Perspective of Entrepreneurship: Entrepreneurial Legitimacy as Habitus. Int. Small Bus. J. 2009, 27, 395-419. [CrossRef]

85. Cardinale, I. Beyond Constraining and Enabling: Toward New Microfoundations for Institutional Theory. Acad. Manag. Rev. 2018, 43, 132-155. [CrossRef]

86. Pache, A.-C.; Santos, F. Embedded in Hybrid Contexts: How Individuals in Organizations Respond to Competing Institutional Logics. In Institutional Logics in Action, Part B; Lounsbury, M., Boxenbaum, E., Eds.; Emerald Group Publishing: Bingley, UK, 2013; p. 3.35.

87. Gioia, D.A.; Thomas, J.B.; Clark, S.M.; Chittipeddi, K. Symbolism and Strategic Change in Academia: The Dynamics of Sensemaking and Influence. Organ. Sci. 1994, 5, 363-383. [CrossRef]

88. Maitlis, S.; Christianson, M. Sensemaking in Organizations: Taking Stock and Moving Forward. Acad. Manag. Ann. 2014, 8, 57-125. [CrossRef]

89. Lévi-Strauss, C. The Savage Mind; University of Chicago Press: Chicago, IL, USA, 1966.

90. Baker, T.; Nelson, R.E. Creating Something from Nothing: Resource Construction through Entrepreneurial Bricolage. Adm. Sci. Q. 2005, 50, 329-366. [CrossRef] 
91. Evans, S.; Vladimirova, D.; Holgado, M.; Van Fossen, K.; Yang, M.; Silva, E.A.; Barlow, C.Y. Business Model Innovation for Sustainability: Towards a Unified Perspective for Creation of Sustainable Business Models. Bus. Strateg. Environ. 2017, 26, 597-608. [CrossRef]

92. Pache, A.-C.; Santos, F. When Worlds Collide: The Internal Dynamics of Organizational Responses to Conflicting Institutional Demands. Acad. Manag. Rev. 2010, 35, 455-476. [CrossRef]

(C) 2019 by the authors. Licensee MDPI, Basel, Switzerland. This article is an open access article distributed under the terms and conditions of the Creative Commons Attribution (CC BY) license (http://creativecommons.org/licenses/by/4.0/). 